\title{
STATE SOVEREIGNTY, INTERNATIONAL HUMAN MOBILITY AND HUMAN RIGHTS
}

\author{
SOBERANIA DO ESTADO, MOBILIDADE HUMANA INTERNACIONAL E DIREITOS
}

HUMANOS

Luís Renato Vedovato

Doutor em Direito Internacional pela Faculdade de Direito da Universidade de São Paulo. Professor do Mestrado em Direito da UNINOVE.

E-mail:1rvedovato@gmail.com

\section{Samyra Haydêe Dal Farra Naspolini}

Doutorado em Direito pela Pontifícia Universidade Católica de São Paulo.Pesquisadora e professora permanente do Mestrado em Direito da Universidade Nove de Julho - UNINOVE e da Universidade de Marília UNIMAR.

E-mail:samyranaspolini@gmail.com

Recebido em: 04.02.2016

Aprovado em: 15.02.2016

DOI: $10.5585 / \mathrm{rdb} . \mathrm{v} 12 \mathrm{i} 5.341$

\begin{abstract}
International human mobility and human rights can be linked by the dinamogenesis theory. The State sovereignty isn't the same it was in the past. The right to have a nationality unites people and States. The State cannot decide about the right to entry without consider international human rights treaties. The nationality has an important row in finding how dinamogenesis can modify the interpretation of the State sovereignty. The right to entry is built in the evolution of human rights. Now, with the new interpretation of sovereignty, State has no more the discretion to decide who can enter its territory, due to dinamogenesis and human rights.
\end{abstract}

Key words: human rights; nationality; migration; right to entry; dinamogenesis. 


\section{RESUMO}

A mobilidade humana internacional e os direitos humanos podem ser conectados pela teoria dinamogenesis. A soberania do Estado não é a mesma que era no passado. $\mathrm{O}$ direito a ter uma nacionalidade une as pessoas e Estados e dessa forma precisa ser compreendido no cenário dos direitos humanos. $\mathrm{O}$ Estado não pode decidir sobre o direito de entrada sem considerar os tratados internacionais de direitos humanos. A nacionalidade tem uma linha importante na busca de como a dynamogenesis pode modificar a interpretação da soberania do Estado. O direito de entrada é construído na evolução dos direitos humanos. Agora, com a nova interpretação da soberania, Estado não tem mais o poder de decidir quem pode entrar no seu território, devido à dinamogenesis e aos direitos humanos.

Palavras-chave: direitos humanos; nacionalidade; migração; direito de entrada; dinamogenesis

\section{INTRODUCTION}

The concern that created this paper lies, on one hand, in a possible regulation of the one's right to enter in a foreign country ${ }^{1}$, and, on other hand, the evolution of human rights, considered granted with the characteristic of what is called dinamogenesis. Historically, the Statehas received the mandate to decide, irrefutably, on the entry of foreigners into its territory; however, the evolution of the international protection of human rights brought impacts to this faculty. What it's important to investigate is if there is a limit to the decision taken by the primary subject of international law, namely the State, in order to grant the permission to a human being to enter its territory.

The Vitoria's theory about the jus communicationis is relevant for the development of the present article, exactly because of the freedom of human mobility defense. But it's not only this theory that is for the right to enter. In addition to Vitoria's ideas, which

\footnotetext{
${ }^{1}$ According to Carvalho Ramos, the definition of foreigner is made by exclusion, as follows "A princípio, estrangeiro é todo aquele que não possui a nacionalidade do Estado em cujo território se encontra. Por exclusão, então, a doutrina tradicionalmente define o estrangeiro como sendo o nãonacional, quer tenha outra nacionalidade, ou seja, apátrida" (CARVALHO RAMOS, A. Direito dos Estrangeiros no Brasil: imigração, direito de ingresso e os direitos dos estrangeiros em situação irregular. In: SARMENTO, D.; IKAWA, D; PIOVESAN, F. (Coord.). Igualdade, diferença e direitos humanos, p. 721).
} 
defends the full freedom of movement for everyone, there are International Courts decisions that permits to think about a right to enter, highlighting in particular the Advisory Opinion number 18 of the American Court of Human Rights, published in September $17^{\text {th }}, 2003$, which recognizes the need to create, by the State, a migration policy, allowing one to glimpse a limitation to the State's powers to decide on the entry of foreigners.

So, the veto to the plea of entrance must be made according to the State migration policy and cannot, according to the Court, violate international human right treaties. The space for support of State decision is narrow and restricted to the arguments brought in its foundation, seeing up in this way, there is a possibility to apply the logic of tragic choices ${ }^{2}$ also in this case.

With the concept of dinamogenesi ${ }^{3}$, it is possible to understand the reason why the State Sovereignty is different now of what it was in the past. The human rights are at the center of the answer, and, mainly, in the right to enter in a foreigner country subject, the human rights have been facing changes, due to the evolution of their interpretation.

\section{INTERNATIONAL HUMAN MOBILITY AND THE LIMITATIONS OF STATE SOVEREIGNTY}

The expression international human mobility is used to identify the international circulation of people, which were increased by the technology and the globalization. The point of this work is the right of entry; however, in the field of international human mobility, it is important to identify the existence of various adjustments to the exit and entry of people.

Regarding the freedom to leave the State's territory, it isfirst placed in the Magna Carta, $1215^{4}$, which established that everyone has the right to leave England. After

\footnotetext{
${ }^{2}$ Bobbit \& Calabresi, 1978.

${ }^{3}$ SILVEIRA, V. O. ; María M. Rocasolano . Direitos Humanos: conceitos, significados e funções. São Paulo: Saraiva, 2010.

${ }^{4}$ WEISSBRODT, D. S.; DANIELSON, L. Immigration Law and Procedure in a Nutshell. 5. ed. New York: Thomson West, 2005. p. 366.
} 
that, the common law, in the same country, gave birth to a legal instrument called $\mathrm{Ne}$ Exeat Regno ${ }^{5}$, which allowed the king to prevent the departure of certain individuals. The right to leave the territory of the State has been recognized generally after World War II, in particular on account of the United Nations Charter and the Universal Declaration of Human Rights (UDHR).

The biggest dilemma faced wasn't spelled out by the Universal Declaration of Human Rights, and involves the guarantee of rights to foreigners and their right to entry, due to the expansion of the movement of people around the world.

According to the European Court of Human Rights in 2002, at the trial Boultif vs. Switzerland, there is no right of entry, conclusion that leaves the individuals at the sole discretion of the State, without any possibility of external control over this issue. What it can't be found in the European decision is the necessary comparison between the international human rights and the reasons for the hindrance of admission. Actually, the decision didn't consider the influence of human rights in raising limitations to State sovereignty ${ }^{6}$.

The large circulation flow of people around the world, however, cannot be ignored; therefore, the Advisory Opinion n. 18 of the American Court of Human Rights is of paramount importance to build the limitation to the decisions of States as a logical consequence of international treaties on human rights protection as regards their relationship with foreigners.

In this context, it is possible to identify that the movement of people around the world is becoming more intense. Communications are facilitated and physical displacements become faster. It is noteworthy, in this scenario, the performance of the State receiving the migrant.

Total State discretion to decide who enters in its territory denotes no longer exist, because received limitations, in particular the construction of the protection of human

\footnotetext{
${ }^{5}$ Ibidem, p. 366.

${ }^{6}$ According to Convey and Kupiszewski, : "There is an inescapable relationship between the existence of migration movements and the resulting policies which are adopted by the authorities of the area concerned towards encouraging these movements, or more commonly towards attempting to control or to reduce them. This in turn means that the migration researcher must not only look at the effects of policy and changes in policy, important though this is, but must also attempt to understand the changing political factors which fuel the formation of policy." (CONVEY, A.; KUPISZEWSKI, M. Keeping up with Schengen: migration and policy in the European Union. International Migration Review, v. 29, n. 4, p. 939-963, 1995. p. 939).
} 
rights, which prevent the State from continuing to act in the same way that he acted before the current facilities flow of information and people exist.

Identify these limitations, arising from the implementation of human rights treaties, which would serve to contain the complete discretion of the Stateand control its activity, is at the heart of the object of this article.

In other words, the aim is to identify whether there is a right to enter in the face of State power to determine who may or may not enter their territory.

Total State's discretion decision, either because there are no absolute rights or by the universality of human rights, can be regarded as non-existent these days, due to the construction of international standards that limit the State sovereignty.

The backdrop is the finding of a world with a growing transnational interaction, which deepens with the increase in technology, in particular on the communications, increasingly fast and affordable ${ }^{7}$. As products of globalization, the effects of Stateinternal decisions are increasingly perceived beyond the borders hosting nations. That's the reason why an internal migration public policy has sensible effects in people from around the world.

Both issues pertaining to international trade and migration law, which clearly always brought consequences beyond the limits of application of national law, as in matters that were traditionally affected solely to domestic law, for example, procedural law, already see the existence of links that can be cross-border calls.

In this sense, international cooperation and procedural forum for election in international contracts may be cited exemplarily ${ }^{8}$.

The legal globalization was examined by Matias ${ }^{9}$, in which the author explains about the legal interdependence between States ${ }^{10}$. It's possible to see that even the most unpretentious internal decisions can bring sensitive international reflexes, and it's no different with migration and nationality law ${ }^{11}$.

\footnotetext{
${ }^{7}$ About the globalisationinfluencea on migration and citizenship: RUBENSTEIN, K. Globalisation and citizenship and nationality. SSRN eLibrary. 2003: <http://ssrn.com/paper=530382>.

${ }^{8}$ In that point, check: GASPAR, R. A. Reconhecimento de sentenças arbitrais estrangeiras no Brasil. São Paulo: Atlas, 2009. (Coleção Atlas de arbitragem).

${ }^{9}$ MATIAS, E. F. P. A humanidade e suas fronteiras do estado soberano à sociedade global. São Paulo: Paz e Terra, 2005. p. 203.

${ }^{10}$ HUCK, H. M. Sentença estrangeira e Lex Mercatoria:horizontes e fronteiras do comércio internacional. São Paulo: Saraiva, 1994. p. 38.

${ }^{11}$ According to Rozas and Alvarez González: "Desde una primera dimensión, de carácter sociológico, la nacionalidad es expresión jurídica de un hecho social, es decir, la pertenencia de una persona a una comunidad nacional. Sin embargo, para una segunda concepción, que hoy dia puede calificarse de
} 
It is therefore natural to recognize the need to expand the protection of individuals, regardless of nationality or domicile, before of national and transnational decisions; that more and more commonly affect people from all over the world. In other words, the individual begins to suffer the consequences of decisions taken by States with which it has no relation - of nationality or any other - in which do not participate in the political process, and may not give reputation-represented in these decisions.

The right to nationality is a fundamental right ${ }^{12}$, so, at this point, the State is also constrained in its ability to set the parameters for definition of its nationals, as it was decided in the Nottebohm case. Therefore, nationality gives the person a legal bond that can be taken as the basis for its internal legal and social performances, it also offers important consequences at the international level, especially when it brings into focus the diplomatic protection ${ }^{13}$.

An individual who diligently for its inclusion in a territorial community, as the State, must meet certain legal requirements, both for external protection to prevent violations of their rights - the so-called diplomatic protection, which requires the bond of nationality - as to ensure a richer participation in democratic processes of the chosen community, which is allowed in some situations, only with the possession of a residence permission ${ }^{14}$. And that, indirectly, would bring consequences to the world community by more or less global movement of individuals.

The traditional connection with the individual States, for protection has been made, as noted, through the bond of nationality ${ }^{15}$. Individuals gain the status of nationals of a State when it recognizes the link for determining the domestic legislation. With respect to legal entities, although it is the nationality unique attribute of individuals, gives up something like that, with the presence of another type of connection between

dominante, la nacionalidad implica un vínculo entre la persona y el Estado al que se halla sometido.”. (FERNÁNDEZ ROZAS, J. C.; ALVAREZ GONZÁLEZ, S. Derecho español de la nacionalidad. Madrid: Tecnos, 1987. p. 19).

${ }^{12}$ FERNÁNDEZ ROZAS, J. C.; ALVAREZ GONZÁLEZ, S. Derecho español de la nacionalidad. Madrid: Tecnos, 1987. p. 36.

${ }^{13}$ Ibidem, p. 36.

${ }^{14}$ That's what happens to Portugeses in Brazil, that in certainscircunstanceshave the same right of a Brazilian, as written at art. $12, \S 1^{\circ}$, Brazilian Constitution.

${ }^{15}$ SLOANE, R. D. Breaking the genuine link: the contemporary international legal regulation of nationality. Harvard International Law Journal,v. 50, Winter 2009: <http://ssrn.com/paper=1262877>. 
them and the State ${ }^{16}$, consists essentially of a link between legal entities and spatial legal State.

Understand the concept of nationality and the rules on granting and loss, in addition to regulatory requirements relevant to the movement of non-nationals, leads to partial identification of the measure of the permeability of national borders of a particular State. As the national cannot be stopped at the border, identifies, in part, a State action of restriction, which, in turn, cannot deny the entry, as already created the defining rules of nationality.

One can also identify the limitation of the State's right to set the rules on granting the bond to its nationals, changing the focus of the analysis, when one realizes that he can not declare their national all individuals in the world, according explains Santos ${ }^{17}$, to make mention of the case Buchanan vs. Rucker, and underway before the English courts in 1808, culminating with the express declaration that the island of Tobago could not declare their national inhabitants of the world, due to the need for effectiveness of the bond, specific object of analysis in the course of this thesis .

In a sphere still largely belongs exclusively to the State, the nationality decisions can affect both the individual's right to have access to a shield as the substantive content of their rights. In fact, if the State is essential to the individual's relationship with society in which it operates, the State's actions are clearly linked to the rights guaranteed to individuals who are linked to it in the face of nationality. Something identified more clearly by examining the role of rights, in particular social, guaranteed a certain national society.

In addition to setting the standards for entitlement to nationality, States claim a special prerogative to ensure that their national and individuals in its territory domiciled exclusive charges, on, eg, taxation, military service and subject to the civil jurisdiction and criminal.

\footnotetext{
${ }^{16}$ According with Rezek: "Todo o substrato social e histórico do instituto da nacionalidade tende a apontar, de modo inequívoco, apenas o ser humano como seu titular. É por extensão que se usa falar em nacionalidade das pessoas jurídicas, e até mesmo em nacionalidade das coisas. No primeiro caso não há negar valor jurídico ao vínculo, apesar de que fundado quase sempre na mera consideração da sede social ou do lugar de fundação da empresa. No segundo, o uso do termo nacionalidade não excede à metáfora. Assim, a constância com que ouvimos referência a aviões brasileiros ou a sociedades brasileiras de capital aberto não nos deve levar a confundir um vínculo político eminente, dotado de amplo lastro na história das sociedades humanas, com mera sujeição de ordem administrativa, mutável ao sabor da compra e venda" (REZEK, J. F. Direito Internacional Público: curso elementar. 11. ed. São Paulo: Saraiva, 2008. p. 180).

${ }^{17}$ SANTOS, A. M. dos. Estudos de direito da nacionalidade. Coimbra: Almedina, 1998. p. 281.
} 
The allocation to States the responsibility to protect individuals and render decisions that most directly affect this assignment, given a decentralized global arena in which nation-States are still the main official participants, therefore, should be considered, particularly if the individual does not have a State as protector, which can be seen as the community aspiration for realization of human rights by State action.

Regarding that, it is worth noting that by the nationality that the State determines the scope of their personal competence on a population of permanent and stable individuals within its territory and also outside of it, both in areas that are part of another territory, in its extraterritorial jurisdiction, the international public domain regions such as the high seas and parts of Antarctica18.

The Stateless person, the person without formal membership of a political body, is, accordingly, identified as an international pariah, a person "unprotected", facing hardship not to receive the support of a State - hardships that are serious and comprehensive, very beyond those common to foreigners. The Stateless person has little or no protection, both internal and internationally, against State decision, imposed on it, it has no or limited space for political participation.

Foreigners, who are nationals of any other State, also suffer rights restrictions, even though, in theory, a protector on the international stage, which may prove weak or have geopolitical interest of defending its national by way of diplomatic protection.

Similarly, in some situations, the individual faces administrative obstacles and legal complexities to have recognized their nationality and, after that, that the government granting it to him will protect it at the international level and can thus also pass deprivation of rights related to the merits of their claim.

The practices of States for the award or denial of nationality and the procedures that they have set for this may, in fact, directly affect not only access to a guard, but also the quantity and quality of participation in all internal decision-makers citizenship.

Emerge hence the need for, research on actual and potential deprivation of human rights, is made a detailed examination of the logic of the decision about the practical and the granting and denial of nationality procedures, or even about permission or

\footnotetext{
${ }^{18}$ FERNÁNDEZ ROZAS, J. C.; ALVAREZGONZÁLEZ, S. Derecho español de la nacionalidad, p. 39: “[...] el ámbito de su competencia personal sobre una población de individuos permanentes y estables en su territorio e, incluso, fuera de él, tanto en áreas que no formen parte del territorio de otros Estados (alta mar, partes de la Antártida, espacio ultraterrestre, etc.), como en el territorio de otros Estados dentro de la denominada competência extraterritorial del Estado".
} 
prohibition of entry into foreign territory, which, in general, will determine the degree of State permeability to non-national ticket.

Hence nationality has great relevance for international law and can be identified as essential in the relationship between individuals and States, with base, as noted, eg, for the granting of diplomatic protection. In the words of Rubio Carracedo et al ${ }^{19}$. Where it is argued that democracy and popular sovereignty demands the opening of a space for public debate and the exercise of approximation of the groups, which should be seen as more than mere tolerance among them, however, points out that nationality is the response to determine who is part of these groups that deserve to be heard in the political discussion.

The permeability of national borders should be seen not only as the easy ways in which words and images move in an internet not limited by geographical constraints, but also by the movement of people across national borders in the real world.

In the early twentieth century, according to Benhabib and Resnik ${ }^{20}$, almost $2 \%$ of the population - 33 million of the total 1.7 billion people - lived in the situation of migrants, while in 2000, about 175 million people lived and foreign, a total of 6 billion people in the world. This brings the percentage to something very close to $3 \%$ of the world population living as migrants in addition to the significant increase in absolute numbers.

This article, which deals with the permeability of national borders and on the basis of the decisions of States, shows to be relevant because, in the last 30 years of the twentieth century, some 75 million people left the country in which they lived - as or foreign and domestic - and were living in other parts of sites. The migrant, then, is defined as one that leaves a State to settle permanently in another. And this must create impacts on State Sovereignty, because of the dinamogenesis.

\footnotetext{
${ }^{19}$ RUBIO CARRACEDO, J. ROSALES, J. M.; TOSCANO MÉNDEZ, M. Ciudadanía, nacionalismo y derechos humanos. Madrid: Editorial Trotta, 2000. p. 97. (Colección Estructuras y procesos): "Si pensamos en la democracia como soberanía popular, también parece claro que la apertura de un espacio de debate público y el ejercicio de la acción colectiva ya no permiten el aislamiento de cada grupo en su enclave y exigen algo más que la mera tolerancia entre comunidades; requieren un nuevo sentido de comunidad y solidariedad entre los individuos que componen el cuerpo político. La nueva legitimidad democrática remite a una comunidad de ciudadanos capaces de afirmar 'We, the people', por lo que surge necessariamente la cuestión de quiénes constituyen ese 'nosotros' y cómo se define esa identidad colectiva. [...] la nacionalidad es la respuesta moderna a esta clase de cuestiones."

${ }^{20}$ BENHABIB, S.; RESNIK, J. Migrations and mobilities: citizenship, borders, and gender. New York: NYU Press, 2009. p. 1.
} 
In this context, the issue of universality is central, as the basis for the right to movement of people around the world. Looking up, then, to understand whether the nationality may be grounds for admission of hindrance in another country and in what situations it can occur ${ }^{21}$.

Indeed, it is disturbing the relationship between the universality of human rights and the impossibility of free movement of people around the world, especially in cases where the refusal of admission is done as a total restriction of rights.

The entry of foreigners in the territory, however, it should be a decision of the receiving State. Aside from the refugee protection cases crystallized in international treaty, the permeability of national borders is linked to the possibility of realization of social rights, which justifies the need to reserve to the State the decision on the entry of foreigners into its territory, that, in essence, should be understood as a decision involving scarce resources, with deep connections to the discussion regarding the Law and Economics (Law \& Economics), constituting a tragic decision, as identified by Calabresi\& Bobbitt ${ }^{22}$ and by Elster ${ }^{23}$.

This decision, however, need to be of rationality, because if it does not, foreigners can be chosen randomly, in a procedure that must be rejected by the law. Understanding the relationship between universality and immigration, in the light of the necessary logical structure, and contribute to a form of control of Statedecisions ticket or not foreign to guide the evolution of the discussion from now.

Undeniable, the theory of dinamogenesis is fundamental to understand the evolution of the right to entry interpretation. In the middle of $20^{\text {th }}$ Century, it was impossible to accept the freedom in international human mobility, but, now, after the celebration of human rights treaties and the new law interpretation, it is totally possible to make the right to entry effective, creating limitations to State sovereignty due to the application of the dinamogenesis of human rights.

\section{MIGRATION AND LAW OF NATIONALITY}

\footnotetext{
${ }^{21}$ RUBIO CARRACEDO, J. ROSALES, J. M.; TOSCANO MÉNDEZ, M. Ciudadanía, nacionalismo y derechos humanos, p. 103.

${ }^{22}$ CALABRESI, G.; BOBBITT, P. Tragic choices. New York: W. W. Norton \& Company, 1978.

${ }^{23}$ ELSTER, J. Local Justice: how institutions allocate scarce goods and necessary burdens. New York: Russell Sage Foundation Publications, 1993.
} 
The regulation of migration reflects, in each country, public opinion and the political attitude abroad ${ }^{24}$. In some States, it is complex and its pieces do not always fit well and can change constantly; in others, there is a reasonable regulation with clear regulations that remains for long periods. The creation of a system or a logical structure, shows up as a challenge that is faced with a difficult puzzle to be unraveled in legal terms but easy intelligibility in politics harvest, represented by the attempt to seek the foundation for State decision distanced from the legal logic, but close to the political influences and moods of international relations.

It is true, however, that the debate on migration has been constantly encouraged by dramatic events shown by the print and broadcast media, as the image of Cubans going to the coast of Florida in the Mariel Boatlift in 1981, or the stampede of tens of thousands of Haitians also to Florida, agglomerated in fragile boats, and doing refuge requests. Or, the arising of the difficulties, since 2008, by Brazilians who tried to enter, sometimes as simple tourists, in a foreign country, especially in Spain.

In the images of New Year's Eve night in Mexico 25 (2007/2008), via that, under a huge banner reading "Sin no hay corn country" ("Without corn there is no country"), thousands of farmers formed a human chain in Ciudad Juárez, on the border with the United States. It was fourteen years of signing the North American Free Trade Agreement (NAFTA), established on January 1, 1994 between Canada, Mexico and the United States. The impact, however, to move beyond, minimum people, while via an increase in the movement of agricultural products, object of those protests.

Immigration is also identified in the images of the 11 September 2001 attacks on the World Trade Center and the Pentagon, as they were allegedly carried out by hijackers who entered the United States, by law, such as immigrants ${ }^{26}$.

\footnotetext{
${ }^{24}$,ALEINIKOFF, T. A. Citizenship policies for an age of migration. Washington, D.C: Carnegie Endowment for International Peace, 2002. p. 37.

25 "In 2001 the United States Immigration and Naturalization Service ordered Rosario Hernandez of Garland, Texas, deported to his native Mexico. Hernandez, a 39-year-old construction worker, had immigrated to Texas from Guadalajara, Mexico, when He was a teenager. His removal was ordered on grounds that he had been convicted three times for driving while intoxicated - twice nearly twenty years ago and once ten years later." (NGAI, M. M. Impossible subjects: illegal aliens and the making of modern America. New Jersey: Princeton University Press, 2005. p. 1).

${ }^{26}$ GUISAN, C. Of September 11, Mourning and cosmopolitan politics.Constellations: An International Journal of Critical \& Democratic Theory, v. 16, n. 4, p. 563-578. DOI: Article, 2009.
} 
After the attacks, became part of the texts published in the United States, including in the academic world, the concern with the creation by the US Congress, a rational system to select the categories of persons whose admission will serve the interests, particularly the economic, the country that receives immigrants ${ }^{27}$.

Based on this, it can be said that what differentiates the national foreign or Stateless person is, of course, the nationality. Since the dawn of classical international law, conventionally originated with the Peace of Westphalia, 1648, nationality has been an essential support system. Indeed, as States were the subject only of international law, nationality became an indispensable legal concept, it allowed the construction of the link between the individual and the right of nations ${ }^{28}$.

Nationality is the mediator of the rights and obligations of individuals in relation to States in several areas, including diplomatic protection, the war, the responsibility of the State and extradition ${ }^{29}$; however, nationality has a difficult definition content, described by Holmes as having multiple variations depending on the time in which it is used, as defined individually by State ${ }^{30}$, may change due to the political needs of each country 31 .

Occurs, so that while the nationality have vital roles in international law, in order that States can, eg, create laws governing their national and defend their rights, as in the case of diplomatic protection, the legal consequences more important of nationality remain internally ${ }^{32}$, involving essentially the rights given to national and obligations to which they are subjected by the State which confers such rights.

International law, partly for this reason it offers ample scope to the States to confer nationality ${ }^{33}$. The Permanent Court of International Justice (PCIJ), for its part, stated in case of Nationality Decrees of Tunisia and Morocco, which nationality fall within

\footnotetext{
${ }^{27}$ GREENWOOD, M. J.; HUNT, G. L.The early history of migration research.International Regional Science Review, v. 26, n. 1, p. 3-37. DOI: 10.1177/0160017602238983, 2003. p. 21.

${ }^{28}$ JONES, M. Lies, damned lies and diplomatic assurances: the misuse of diplomatic assurances in removal proceedings. European Journal of Migration \& Law, v. 8, n. 1, p. 9-39. DOI: Article, 2006.

${ }^{29}$ JENNINGS, Robert; WATTS, Arthur (Eds.).Oppenheim's International Law, n. 849, 857-859.), 9th ed. 1992); BROWNLIE, I. Principles of Public International Law, n. 374, 6th ed. Oxford: Oxford University Press, 2003.

${ }^{30}$ Towne $v$. Eisner, 245 U.S. 418, 425 (1918).

${ }^{31}$ GRAMSTRUP, Erik Frederico ; HENRIQUE, Luciana Alves ; FLORESTANO, Miguel ; OLIVEIRA, Roberto Silva ; JUCOVSKY, Vera Lucia . Da Extradição. In: Wladimir Passos de Freitas. (Org.). Comentários ao Estatuto do Estrangeiro e Opção de Nacionalidade. 1a ed. Campinas-SP: Millennium, 2006.

${ }^{32}$ Nottebohm (Liech. v. Guat.), 1955, CIJ 4, 20.

${ }^{33}$ Nottebohm (Liech. v. Guat.), 1955, CIJ 4, 20.
} 
the area of legal competence reserved for internal law, although it may be limited by obligations under international law ${ }^{34}$.

As can be seen in the art. 3, paragraph 2, of the European Convention on Nationality, nationality has no clear regulation by international law: it permeates the international legal system ${ }^{35}$, however, this relegates its definition and regulation system, with rare exceptions, almost invariably, to the various legal systems ${ }^{36}$.

The fact pointed stems from the traditional role of nationality, as the intermediary between the individual and the State, is therefore indispensable to many areas of international law. In this step, the State may, eg, defending national of claims - but only of its nationals -; determine the right to exercise extraterritorial jurisdiction over their nationals and, increasingly, on those who cause damage to nationals; in addition to enforce humanitarian law to its citizens who rely on protection afforded to them by the Geneva Conventions.

With the construction of international human rights law, it is possible to identify the creation of obligations for States in relation to its own nationals. You can also check the importance of citizenship in the contemporary international system for the protection of refugees and their relevance with respect to protection of foreign investors, supported by a kind of investor center, which restricts the powers of the States to regulate themes related to foreign investment.

In contemporary times, instruments are identified that provide background protection for foreign investments, including, eg, bilateral treaties of -the called BITs investment.

International law has not yet, however, with rare exceptions, a group of standards intended to control the power, so far, sovereign States to define the internal rules on nationality. The classic international law refers to the granting of citizenship as a matter of national law, only subject to limitations based on the will, as brought by a treaty and to some extent also by customs and general principles, as pointed out here. In 1923, the Permanent Court of International Justice (PCIJ) determined that "in principle" the nationality should remain in the "reserved area" of the national legal

\footnotetext{
34 Opinion, 1923, PCIJ, n. 4; see also,PCIJ n. 7, 1923.

${ }^{35}$ RUBENSTEIN, K.; ADLER, D. International Citizenship: the future of nationality in a globalised world. SSRN eLibrary.2000, p. 519, 525.<http://ssrn.com/paper=231675>.

36 Panevezys-Saldutiskis Railway (Est. v. Lith.), 1939 P.C.I.J. (ser. A/B) No. 76, 16 (Feb. 28).
} 
jurisdiction, although States could voluntarily accept the limitations imposed by the treaty.

With mainstay in the "general rule" set in the case of Polish nationality, PCIJ's arguments denoting the purpose of referring not only to the limitations that the Statecan accept voluntarily through agreements with other States, but also the limitations imposed on them the freedom of a State to determine the nationality of individuals.

Thus, the custom and the general principles, not only obligations under the Treaty, would build the domain boundary booked the competence of States to confer nationality. But the argument did not specify the nature or the content of such limits. In 1929, as explained in specific point of this study, research at Harvard Law School culminated in a draft convention and comments on the international regulation of nationality.

The draft convention, born of studies at Harvard, as stipulated in 192937, each State may, by its domestic law, determine who are its nationals, subject to the provisions of the special treaty that the Statecan be part. Under international law, however, the power of a State to confer its nationality is not unlimited, turning thus for the vagueness of the content of the concepts and limits.

It can be seen, therefore, that the interference of international law in the internal regulation of nationality is quite modest. It will be appropriate to bring to light the example cited by Sloane ${ }^{38}$, on freedom of States regarding the granting of nationality, in which, at the end of the Bolshevik Revolution, Russia has proposed to grant Russian citizenship to all workers of the world .

In this situation, is identifiable wide discretion given to States because it can be difficult to determine the limitations that exist in international law on the power of a State to confer its nationality. Obviously there are some limitations. In theory, a State could grant nationality to anyone, even to those had no relationship. The limitation, however, appeared in the Nottebohm case, but without enough strength to change clearly international law, restricting themselves to determine that nationality should be continuous and effective, as will be discussed.

\footnotetext{
${ }^{37}$ The Law of Nationality art. 2, 23 AM. J. INT'L L. SPEC. SUPP. 11, 13 (1929).

${ }^{38}$ SLOANE, R. D. Breaking the genuine link: the contemporary international legal regulation of nationality. Harvard International Law Journal,v. 50, Winter 2009. < http://ssrn.com/paper= $\underline{1262877>}$.
} 
It is recalled that the present investigation aims to focus on the relationship between Stateand individual born of the right to nationality and migrant status, in order to lend logicality the decision to allow the entry of migrants in the national territory, and identify levels of permeability of national borders.

It is understood that the total freedom of the State to define who enters its territory disappeared with the emergence of international human rights treaties. Identify the limits of the State's decision and understand if those limits can create standards for such decisions is therefore the main focus of this thesis.

\section{NATIONALITY AND THE OTHERS - ONE MORE REASON TO EXCLUSION}

The disagreements between France and Italy, in the episode of the Tunisians in Ventimiglia, Italian city, has the origin of the exclusion of the foreigners. In April 2011, the French government decided to deny the entry in its territory of Tunisians, with input authorization given by Italy ${ }^{39}$. The fact was understood as violation of the Schengen agreement, by which it allows free movement of people around the block, provided that in the case of foreigners, passed through immigration control of the countries of the European Community.

These cases, although they represent a microcosm, show that the exclusion does not affect only foreigners. The exclusion attacks those who are identified as "other", which, for the realization of social rights, are those who can not contribute to expand the range of resources aimed at the satisfaction of these rights. American Indians reached the full right to US citizenship only in 1924.

On the same basis to be understood as part of the "other", the foreigner is seen as one that will not help, however, will enjoy social rights or opportunities reserved before only to nationals, consisting in that their main objectives for the pursuit of entry into foreign territory, as Honig ${ }^{40}$ recognizes that there are several proposed solutions, however, in all cases, the question is treated as a "problem."

\footnotetext{
${ }^{39}$ CONVEY, A.; KUPISZEWSKI, M. Keeping up with Schengen: migration and policy in the European Union. International Migration Review, v. 29, n. 4.

${ }^{40}$ HONIG, B. Democracy and the foreigner. New Jersey: Princeton University Press, 2003. p. 1: "'How should we solve the problem of foreignness?' The question underlies contemporary discussions of democracy and citizenship. Proposed solutions vary. Political theorists deliberate about whether or to what extend social unity is necessary to sustain social democracy. Courts rule on the extent of
} 
According to the statistics available, both absolute and relative way, there was never such a large amount of international migrants as exists today and their number is certainly a growing ${ }^{41}$. Almost all countries of the world are and will remain affected by the increased movement of people across the globe.

A State is positioned on the international stage for its migration policy therefore not only demonstrates the view that the State has of itself, but shows signs of its position in the world and its relationship with other States, which suggests that the extern policy has clear links with immigration policy ${ }^{42}$.

It is crucial to understand, however, that migration is inextricably linked to other important global issues such as poverty, development and human rights. Despite the negative view that awaken the national, migrants, according $\operatorname{Koser}^{43}$, are the most entrepreneurial and dynamic members of society in which they live. The author also adds that, historically, migration sustained economic growth and nation building as well as being responsible for the enrichment of various cultures, eg, as happened with Brazil and the United States.

The other side of the coin is the fact that migration brings hardship to the countries of origin of these people, who fail to have their skills and expertise and can, thus, generate gaps in the countries from which they came.

The migrant status is determined by the person is - or try to join - in a country with which does not have the bond of nationality, set, of course, the sovereign State, which, in fact, have the ability to regulate foreign transit through its borders ${ }^{44}$. This Statereaches, therefore, support in international law which recognizes the sovereign

government's obligations to its noncitizen residents. Economists debate the costs and benefits of immigration. Sociologists argue about the (in)effectiveness of multilingual education. But, notwithstanding their differences, participants in contemporary debates about foreignness all reinscribe foreignness as a 'problem' that needs to be solved by way of new knowledge, facts, or politics. In so doing, they reiterate the question that has dominated political theory for centuries."

${ }^{41}$ MEYER, M. The year that changed the world: the untold story behind the fall of the Berlin Wall. New York: Scribner, 2009. p. 7.

${ }^{42}$ NGAI, M. M. Impossible subjects: illegal aliens and the making of modern America, p. 9: "Immigration policy not only speaks to the nation's vision of itself, it also signals its position in the world and its relationships with other nation-states. At one level this means that foreign policy invariably becomes implicated in the formulation of immigration policy."

${ }^{43}$ KOSER, K. International Migration: a very short introduction. Oxford: Oxford University Press, 2007. p. 24.

${ }^{44}$ About migration: "the concept of the migratory process sums up the complex sets of factors and interactions which lead to international migration and influence its course" (CASTLES, S.; MILLER, M. J. The age of migration.International Population Movements in the Modern World. 4th ed. New York: The Guilford Press, 2009. p. 21). 
right to regulate or prohibit the entry of foreigners into its territory ${ }^{45}$. According to Castles and Miller ${ }^{46}$, migration is a process that affects all existing social dimension, which develops in its own complex dynamics.

In the wake of Castles and Miller ${ }^{47}$, it is interesting to note that $97 \%$ of the population is non-migrant, however, suffers the consequences of migration because their communities are changed by this process.

Find the legal basis for the decision to permit or foreign entry ban is part of the objective of the present work, however, it is essential that presented a brief construction of the right to nationality and, therefore, of its reflections on the migrant's life.

The aforesaid construction can also serve to understand the reasons why, in some situations, regulation brought by the sovereign State may change by agreements between States, aimed at increasing the protection of its nationals in other territories.

Based on these agreements, often bilateral, each State participant shall, in foreign territory, ambassadors and consular officials who its citizens can seek support if facing legal problems in the receiving country. These agents have, then, the mode to protect their countrymen against persecution or any unfair treatment.

As Stateswere always thought to be the main subject of international law, nationality became an indispensable legal concept, forming, as pointed out by Jones ${ }^{48}$, "the link between the individual and the right of nations".

To fully understand the emergence of the nationality link, it is salutary to understand an important period of Western history. Sixty years before the First World War witnessed a momentous transformation in the European State system.

The Italian and German unification, the expulsion of the Ottomans from Southeast Europe, the destruction of the three still remaining empires (Austrian, German and Russian), as victims of war, to be replaced by a group of successor States from the Baltic to the Balkans completely changed the face of Europe, who attended the last dynastic States gave way to nation-States.

\footnotetext{
${ }^{4}$ VALS, P. La nacionalidad. Revista de Derecho Puertorriqueño, Escuela de Derecho de la Pontificia Universidad Católica de Puerto Rico, v. 19, p. 135-240. 1981. p. 189.

${ }^{46}$ CASTLES, S.; MILLER, M. J., op. cit., p. 21: "Migration is a process which affects every dimension of social existence, and which develops its own complex dynamics.".

${ }^{47}$ Ibidem, p. 21.

${ }^{48}$ JONES, M. Lies, Damned lies and diplomatic assurances: the misuse of diplomatic assurances in removal proceedings. European Journal of Migration \& Law, v. 8, n. 1, p. 230, 239.
} 
With the end of World War I, for Europeans, the reconstruction of the continent based on the emergence of nation-States was perfectly understandable. Establish the principles of self-determination and democracy would contribute to peace and prosperity, in particular, solving the problem of nationalities that had caused serious challenges and confusion in the past.

On September 22, 1924, the Fifth Assembly of the League of Nations issued a resolution that paved the way for the creation, by the Board, the Committee of Experts for the Progressive Codification of International Law. The Council set up the said Committee in December 11, 1924, as published February $1925^{49}$.

The work of this Committee made the Assembly of the League of Nations in 1927, determinedthe creation of a Conference on Codification of International Law, making it clear that one of the topics to be covered by it should be the codification of the rules on nationality and determining a schedule of meetings for discussion of the topic for 1928 and early 1929.

Based on these works, in April 1929, came to light a coding project of the rules on nationality, who already in his art. 1, brought a concept of nationality that identified as the link between the individual and the Statethrough fidelity or submission.

\subsection{The battle lost the League of Nations by the codification of international Nationality Law}

On September 22, 1924, the Fifth Assembly of the League of Nations decided to start building an international law codification project. For this determination were met, the Council of the League of Nations created the Committee of Experts for the Progressive Codification of International Law, which met in Geneva in April 1925, January 1926 and end in April 1927, having selected 11 topics for discussion, with the consequent development of its international treaty. For each theme, created a subcommittee, which would be responsible for writing the draft treaty.

The Committee reported directly to the Council of the League of Nations and declared in June 1927 that, after several studies and information exchange, seven of the subjects chosen in 1924 were ready for encoding.

\footnotetext{
${ }^{49}$ League of Nations Official Journal.
} 
The Eighth Assembly of the League of Nations ${ }^{50}$ in September 1927, was nominated to happen in 1929, the holding of an International Conference on Codification of International Law, which was originally supposed to take care of three themes: 1. nationality; 2. waters; and 3. international responsibility of the State for damage caused to foreigners.

The Harvard Law was in charge of organizing research to prepare a text to be submitted to the members of the Expert Committee and subsequently presented at the I Codification Conference.

The choice of nationality as one of subjectswas due to the fact that it showed very relevant discussion of State protection to the individual, with a need to establish a link between particular and subject of international law, in view of the need to resolve the issue concerning the right to nationality minorities absorbed by the world of the new political configuration.

The research resulted in a draft International Convention with 22 articles. Never entered into force, but is a milestone in the advancement of the right to nationality, serving as a relevant factor in the current study of this branch of international law. Also a significant concern at the time was with the people who lived in places that got out of control of a State and passed to the other, being emblematic occurred with the end of the Austro-Hungarian and Ottoman Turkish empires.

Because of this fact, the art. 18 project brought the right individuals of the territory, now the domain of another State, to request the new nationality. Therefore, the project was inspired by the art. 3 of the Treaty of Paris in 1803, by which France ceded the Louisiana Territory to the United States and determined the security of the United States nationality law to the inhabitants of that region.

The same happened in 1867, the treaty in which Russia ceded Alaska to the United States, which also authorized the inhabitants of Alaska to keep Russian citizenship, returning there, or to embrace the new nationality.

In treaty of August 1916, Denmark and the United States decided on the region of the Danish West Indies (current US Virgin Islands), as entered in the report of the experts of the League of Nations ${ }^{51}$, as follows:

\footnotetext{
${ }^{50}$ THE LAW of Nationality. The American Journal of International Law, v. 23, n. 2, p. 66.

${ }^{51}$ THE LAW of Nationality.The American Journal of International Law, v. 23, n. 2, p. 66.
} 
"The treaty of August 4, 1916 between the United States and Denmark, by Which Denmark ceded to the United States the Danish West Indies, provided, in Article 6, for the nationality of 'Danish citizens Residing in Said Islands'. It stipulated que They Might Remain therein of removing therefrom at will, and that 'Those Who Remained in the Islands may preserve Their citizenship in Denmark by making before a court Record, Within one year form the date of the Exchange of ratifications of this convention, the declaration of Their decision to preserve such citizenship. "

The historical moment, however, did not allow to be approved the treaty. Soon after, in particular by virtue of the October 1929 crisis, the League lost ground, since the States had to focus on their domestic economic problems.

\subsection{Historical notes on human displacement across the globe}

Understanding the importance of nationality also is finding its relationship with human displacement worldwide. In fact, the connection with their land and the possibility of joining another company, as well as humanitarian and economic issues, are important parameters for those who decide to migrate, leaving aside the ties with the region to which it is connected.

The history of migration begins with the origins of humanity. Since the beginning there were people who proposed to move the world. According to Ackermann et al. ${ }^{52}$, Africa, in the period extending from 1.5 million to $5000 \mathrm{BC}$, humans have spread across the globe, with the initial target the European continent. In antiquity, the Greek colonization and the Roman expansion in the migration had a great ally. The Inca people, among the Hindus. Also in the Crusades to the Holy Land and release the Viking raids are identified important migration elements. In all of them, there is the building society with the participation of migrant people.

In more recent times, more precisely in the last three centuries, it is possible to identify a number of major events or migration periods. In the eighteenth and nineteenth centuries, the migration was marked by forced displacement of slaves.

\footnotetext{
${ }^{52}$ ACKERMANN, M. E. et al. Encyclopedia of World History. New York: Facts on File, 2008. p. 47.
} 
After the formal end of slavery, many workers from China, India and Japan began to replace the Africans, especially in large plantations of the European powers. About a million and a half of them went to the New World 53 .

The European expansion is also associated with the voluntary withdrawal of large masses of Europeans, particularly for the continent powers of colonies scattered throughout the world. All major market powers such as Holland, France, Spain, Portugal and Britain, promoted and encouraged the departure of their nationals to live in their territories dominated in their colonies. This incentive not only involved workers, but also intended to dissident soldiers, convicts and orphans.

The migration associated with the expansion came to an end with the rise of anticolonial movements started in the second half of the nineteenth century, in years that followed the independence movements, and there was a substantial flow of people returned to their European countries.

The next period of migration the world was due to the rise of the United States as an industrial power. Millions of people from all over the world, for economic or political reasons, fleeing economic stagnation, political persecution and even hunger, went to that country for a period that can be identified between the years 1850 and 1930 . Twelve million of them passed through immigration in New York City, according Diner ${ }^{54}$.

After World War II, starts a new great cycle of migration, since international law recognizing the importance of nationality for international relations. The League of Nations, before 1930, as pointed out earlier, had defined the need to create a global coding for nationality. The European economic growth, according to Leitner ${ }^{55}$, in the period following the year 1946, required labor, which also happened in North America and Australia.

During this period, many Turkish migrants arrived in Germany, while in North Africa were migrants to France and Belgium, in addition to about a million Britons who

\footnotetext{
${ }^{53}$ HEATER, D.A brief history of citizenship. New York: NYU Press, 2004. p. 64.

${ }^{54}$ DINER, H. R. Hungering for America: Italian, Irish, and Jewish foodways in the age of migration. Cambridge: Harvard University Press, 2003.

${ }^{55}$ LEITNER, Helga. International migration and the politics of admission and exclusion in postwar Europe.Political Geography. 1995. p. 260.: <http://www.sciencedirect.com/science? ob= GatewayURL\& method=citationSearch\&_urlVersion $=4 \&$ origin=EXLIBMETA\&_version=\&_uoikey =B6VG2-3Y45T6V-V\&md5=cf93c1b75ef69ff41a9bfccdb43d2845> .
} 
traveled to Australia, whose government drew them to the payment of passage, in addition to the money supply.

During this same period, decolonization still bore impacts on migration in other parts of the world, represented more significantly by the movement of millions of Hindus and Muslims, as a result of the division of India in 1947, as well as Jews and Palestinians, after the creation of Israel in 1948.

In the 1970s, the search for migrant workers, major European attractive in previous years, had ceased. It is true that the period coincides with the end of US resources flow to Europe.

The need for migrant labor continued, despite these challenges, in the United States until the early years of the 1990s; however, one could already identify something that is now quite clear: the great economic growth had shifted to Asia, where still hear the calls of demand for migrant labor, but in smaller proportions, given the large population of that continent ${ }^{56}$.

As can be seen, the history of immigration and nationality has its relevant historical points identified with times of economic changes or regional or global policies. In fact, this is the period in which it is perceived great movement of people around the world.

It is naturaltoo, that there are legislative changes that impact directly on migration. Legislation may be affected by the needs on the entry of foreigners, and therefore is reflected in the possibility of such immigrants attained citizenship.

At this point, it is imperative to note that citizenship, which essentially born of nationality, giving possibility of political participation, is a European legal institution. In fact, both nationality as citizenship have been elements of the legal systems of all European countries since the second half of the nineteenth century, also identifiable in previous periods in several cases.

The referred institutions originated with the modern State, having found its clearest articulation in the nation-State, making room for the increased importance of nationality 57 . It should be noted that the nationality, therefore, is not only a European phenomenon - an institutional integral element of modern European history - but also

\footnotetext{
${ }^{56}$ MOTOMURA, H. Americans in waiting: the lost story of immigration and citizenship in the United States. Oxford: Oxford University Press, 2006. p. 42.

${ }^{57}$ NUSSBAUM, M. C. Frontiers of Justice: disability, nationality, species membership. Cambridge, Mass.: Belknap Press of Harvard University Press, 2007. p. 264.
} 
in relation to its origins and influences a phenomenon, shaped by the distinctive features of each national policies and State specific.

It is important to note that modern democracies owe their stability and success relevant to the union of two ideals that originate in different historical periods: the ideal of self-government and the ideal of the nation-State. Both reflected in the theme of the right of entry and the granting of nationality.

The ideal of self-government defines freedom as the rule of law from a community of equals who are citizens of the polis, according Heater, and thus have the right to govern and be governed. This ideal appears in Athens in the fifth century and is taken over the whole history in episodes such as self-regulation of experience in city-States in the Renaissance, the Paris Commune of 1871, the anarcho-socialist communes of the Russian Revolution and the Spanish Civil War . Based on this ideal, in theory, is founded on the ability of the State to prevent the entry of foreigners in its territory, without the need to justify the decision.

The ideal of the nation-State, in turn, territorially circumscribed, views the citizen first as a subject of the State administration, or, more positively, as a subject of rights and entitlements. Originally from feudalism of the transition experience for the absolutistState, this experience with good governance in self-regulation of civil society has been the definition of the liberal conception of the original social contract in the works of Thomas Hobbes and John Locke. For this ideal, the defending position that the State has complete freedom is understandable to set its own nationals.

The democracy of the seventeenth century and the consolidation of the modern nation-State have marched together, although they may be regarded as contradictory, completing each other. The democratic struggles of those who have goods, artisans, farmers and workers to win the right to vote and the consequent apparent and political inclusion has given rise, in the early twentieth century, the struggle of women, nonChristians and no white people in claiming their inclusion in society. This demonstrates the existence of excluded classes of rights and the constant discussion of their inclusion in the list of beneficiaries, as is currently the case of foreigners. In other words, what did those seeking to protect fundamental rights, the period of 
construction of the standards, in particular social rights, face, today is the challenge of migrants 58 .

One can identify even as emblematic theme of the struggle for rights for migrants. Search a legal rationality in decisions that allow and prohibit the entry of foreign contributes to depart arbitrary decisions. The next step, therefore, is to find the logic in the regulation of nationality.

\section{CONCLUSION}

It's possible to conclude that all the issues regarding international human mobility has change in the last years. Especially because of the human rights dinamogenesis.

The evolution of the interpretation and the necessity of making the human rights treaties effective lead both academic article and International Courts decisions and opinions to understand the right to entry as a fundamental human right. And this happens because of that the reality has had profound changes trough the time.

Exactly like occurred with law of nationality, it can be accept that the State sovereignty is no more absolute. The State is part of international human rights treaties and must act in accordance to them, what impacts directly the decisions about the entry of foreigners in its territory.

It's important to recognize that this evolution is natural and act like a binding force to make human kind able to guarantee the application of rights that can represent the integration of people instead of create the ones who will be called "others".

\section{REFERENCES}

ACKERMANN, M. E. et al. Encyclopedia of World History. New York: Facts on File, 2008.

ALEINIKOFF, T. A. Citizenship policies for an age of migration. Washington, D.C: Carnegie Endowment for International Peace, 2002.

ALEINIKOFF, T. A.; INTERNATIONAL MIGRATION POLICY PROGRAM (U.S.). Between principles and politics: the direction of U.S. citizenship policy. Washington, D.C: Carnegie Endowment for International Peace, 1998.

ALEINIKOFF, T. A.; KLUSMEYER, D. B. Citizenship today: global perspectives

\footnotetext{
${ }^{58}$ BOSNIAK, L. The citizen and the alien: dilemmas of contemporary membership. New Jersey: Princeton University Press, 2008. p. 37.
} 
and practices. Washington, D.C: Carnegie Endowment for International Peace, 2001.

ARAVAMUDAN, S. Sovereignty: between embodiment and detranscendentalization. Texas International Law Journal, v. 41, 2006.

BENHABIB, S.The Rights of others: aliens, residents, and citizens. Cambridge: Cambridge University Press, 2004.

BENHABIB, S.; RESNIK, J. Migrations and mobilities: citizenship, borders, and gender. New York: NYU Press, 2009.

BOSNIAK, L. Persons and citizens in constitutional thought.Int. J. Constitutional Law, v. 8, n. 1, p. 9-29, 2010.

BOSNIAK, L. The citizen and the alien: dilemmas of contemporary membership. New Jersey: Princeton University Press, 2008.

BUZDUGAN, R.; HALLI, S. S. Labor market experiences of Canadian immigrants with focus on foreign education and experience.International Migration Review, v. 43, n. 2, p. 366-386. DOI: 10.1111/j.1747-7379.2009.00768.x, 2009.

CALABRESI, G.; BOBBITT, P. Tragic choices. New York: W. W. Norton \& Company, 1978.

CALDER, G.; COLE, P.; SEGLOW, J. Citizenship acquisition and national belonging: migration, membership and the liberal democratic state. Basingstoke: Palgrave Macmillan, 2009.

CARENS, J. H. Culture, citizenship, and community: a contextual exploration of justice as evenhandedness. Oxford: Oxford University Press, 2000.

CARVALHO RAMOS, A. Direito dos Estrangeiros no Brasil: imigração, direito de ingresso e os direitos dos estrangeiros em situação irregular. In: SARMENTO, D.; IKAWA, D; PIOVESAN, F. (Coord.). Igualdade, diferença e direitos humanos, p. 721-746.

CASTLES, S.; MILLER, M. J.The age of migration.International Population Movements in the Modern World. 4th ed. New York: The Guilford Press, 2009.

DE CUÉllaR, J. P. Manual de derechodiplomático. México: Fondo de Cultura Económica 1997.

DE VRIES, K. An assessment of "Protection in Regions of Origin" in relation to European Asylum Law.European Journal of Migration \& Law, v. 9, n. 1, p. 83-103. DOI: Article, 2007.

DINER, H. R. Hungering for America: Italian, Irish, and Jewish foodways in the age of migration. Cambridge: Harvard University Press, 2003.

ELSTER, J. Local Justice: how institutions allocate scarce goods and necessary burdens. New York: Russell Sage Foundation Publications, 1993.

ElSTER, J.; HYLlAND, A. Foundations of Social Choice Theory: studies in rationality and social change. Cambridge [Cambridgeshire]: Cambridge University Press, 1986.

EULE, T. G. Cosmopolitan anxieties: Turkish challenges to citizenship and belonging in Germany by Ruth Mandel. Nations and Nationalism, v. 15, n. 1, p. 174-176, 2009. DOI: $10.1111 /$ j.1469-8129.2009.00385_4.x. 
GALLOWAY, D. Inevitable Journey. London: Muller, 1974.

GASPAR, R. A. Reconhecimento de sentenças arbitrais estrangeiras no Brasil. São Paulo: Atlas, 2009. (Coleção Atlas de arbitragem).

GOLDSMITH, J. L.; LEVINSON, D. J. Law for States: International Law, Constitutional Law, Public Law (February 10, 2009). Harvard Law Review, 2009; Harvard Public Law Working Paper n. 09-16. 〈http://ssrn.com/abstract=1340615>.

GRAMSTRUP, Erik Frederico ; HENRIQUE, Luciana Alves ; FLORESTANO, Miguel ; OLIVEIRA, Roberto Silva ; JUCOVSKY, Vera Lucia . Da Extradição. In: Wladimir Passos de Freitas. (Org.). Comentários ao Estatuto do Estrangeiro e Opção de Nacionalidade. 1a ed. Campinas-SP: Millennium, 2006.

GREENWOOD, M. J.; HUNT, G. L.The early history of migration research.International Regional Science Review, v. 26, n. 1, p. 3-37, DOI: 10.1177/0160017602238983, 2003.

GROSBY, S. Antinomies of individuality and nationality.Qualitative Sociology, v. 18, n. 2, 2006. <http://www.springerlink.com/content/ a41k85710j41n16k/>.

GUISAN, C. Of September 11, Mourning and cosmopolitan politics.Constellations: An International GUISAN, C. Of September 11, Mourning and cosmopolitan politics. Constellations: An International Journal of Critical \& Democratic Theory, v. 16, n. 4, p. 563-578. DOI: Article, 2009.

HEATER, D.A brief history of citizenship. New York: NYU Press, 2004.

HERZOG, B. Nationalism and multiculturalism in a world of immigration by Nils Holtug, Kasper Lippert-Rasmussen \&Sune.Nations and Nationalism, v. 16, n. 2, p. 375-377. DOI: 10.1111/j.1469-8129.2010.00445_1.x, 2010.

HONIG, B. Democracy and the foreigner. New Jersey: Princeton University Press, 2003.

HUCK, H. M. Sentença estrangeira e Lex Mercatoria:horizontes e fronteiras do comércio internacional. São Paulo: Saraiva, 1994.

JONES, M. Lies, Damned Lies and Diplomatic assurances: the misuse of diplomatic assurances in removal proceedings. European Journal of Migration \& Law, v. 8, n. 1. DOI: Article, 2006.

JÜTERSONKE, O. Hans J. Morgenthau on the limits of justiciability in International Law. Journal of the History of International Law, v. 8, n. 2, p. 181-211. DOI: 10.1163/157180506779884446, 2006.

KLUSMEYER, D. B.; ALEINIKOFF, T. A.From migrants to citizens: citizenship in a changing world. Washington, D.C: Carnegie Endowment for International Peace, 2000 .

KOSER, K. International Migration: A very short introduction. Oxford: Oxford University Press, 2007.

LAUREANO, A. Discriminação inversa na Comunidade Européia: o desfavorecimento dos proprios nacionais na tributação indirecta. Lisboa: Quid Juris?, 1997.

LEITNER, H. International migration and the politics of admission and exclusion in postwar

Europe.Political

Geography.

1995. 
<http://www.sciencedirect.com/science?_ob=GatewayURL\&_method=citationSearch \&_urlVersion $=4 \&$ origin $=$ EXLIBMETA\&_version $=\&$ uoikey $=\mathrm{B} 6 \mathrm{VG} 2-3 \mathrm{Y} 45 \mathrm{~T} 6 \mathrm{~V}$ V\&md5=cf 93c1b75ef69ff41a9bfccdb43d2845>.

LENAIN, P. O FMI. Barueri: Manole, 2004.

LICHTER, D. T.; JOHNSON, K. M. Immigrant gateways and Hispanic migration to new destinations.International Migration Review, v. 43, n. 3, p. 496-518, 2009.

LISSITZYN, O. J. Nottebohm Case (Liechtenstein v. Guatemala). The American Journal of International Law, v. 49, n. 3, p. 396-403, 1955.

MATIAS, E. F. P. A humanidade e suas fronteiras do estado soberano à sociedade global. São Paulo: Paz e Terra, 2005.

MAYADAS, N. S.; ELLIOTT, D. Integration and xenophobia: an inherent conflict in international migration. Journal of Multicultural Social Work, v. 2, n. 1, p. 47-62, 1992.

McGINNIS, J. O.; SOMIN, I. Democracy and International Human Rights Law (July 01, 2009). Notre Dame Law Review, v. 84, n. 4, p. 1.739-1.798, May 2009; Northwestern Public Law Research Paper n. 08-08; George Mason Law \& Economics Research Paper n. 08-19. 〈http://ssrn.com>.

MOTOMURA, H. Americans in waiting: the lost story of immigration and citizenship in the United States. Oxford: Oxford University Press, 2006.

MOTOMURA, H. Immigration Law after a Century of Plenary Power: Phantom Constitutional Norms and Statutory Interpretation. Yale Law Journal, v. 100, p. 545, 1990.

MOTOMURA, H.The Rule of Law in Immigration Law, Tulsa Journal of Comparative and International Law, v. 15, 2007.

NUSSBAUM, M. C. Frontiers of Justice: disability, nationality, species membership. Cambridge, Mass.: Belknap Press of Harvard University Press, 2007.

POMMEREHNE, W. W.; HART, A.; SCHNEIDER, F. Tragic choices and collective decision-making: an empirical study of voter preferences for alternative collective decision-making mechanisms. The Economic Journal, v. 107, n. 442, p. 618-635, 1997.

RUBENSTEIN, K. Globalisation and citizenship and nationality.SSRN eLibrary. 2003. <http://ssrn.com/paper=530382>.

RUBENSTEIN, K.; ADLER, D. International Citizenship: the future of nationality in a globalised world. SSRN eLibrary. 2000. 〈http://ssrn.com/paper=231675>.

RUBIO CARRACEDO, J. ROSALES, J. M.; TOSCANO MÉNDEZ, M. Ciudadanía, nacionalismo y derechos humanos. Madrid: Editorial Trotta, 2000. (ColecciónEstructuras y procesos).

SAIZ, I. Rights in recession?Challenges for economic and social rights enforcement in times of crisis.J. Human Rights Practice, v. 1, n. 2, p. 277-293, 2009.

SANDERSON, L. International mobility of new migrants to Australia.International Migration Review, v. 43, n. 2, p. 292-331, 2009. DOI: 10.1111/j.17477379.2009.00766.x. p. 293.

SANTOS, A. M. dos. Estudos de direito da nacionalidade. Coimbra: Almedina, 
1998.

SARMENTO, D. IKAWA, D.; PIOVESAN, F. Igualdade, diferença e direitos humanos. <http://bdjur.stj.gov.br/dspace/ handle/2011/19004>.

SILVEIRA, V. O. ; María M. Rocasolano . Direitos Humanos: conceitos, significados e funções. São Paulo: Saraiva, 2010.

SLOANE, R. D. Breaking the genuine link: the contemporary international legal regulation of nationality. Harvard International Law Journal,v. 50, Winter 2009. <http://ssrn.com/paper=1262877>.

SMART, W. Eight Modern Essayists. 2th ed. New York: St. Martin's Press, 1973.

SMITH, A. A riqueza das nações. 1. ed., 2. reimpressão. Curitiba: Juruá, 2009.

SOLIMANO, A. Globalization, history and international migration: a view from Latin America. SSRN eLibrary. 2004. <http://papers.ssrn.com/sol3/ papers.cfm?abstract $i d=908241>$.

SOUZA NETO, L. B. C. de. O direito à saúde na Argentina e no Brasil. In: M. L. CETOLIN; S. F.; BRANCO, M. L. A saúde na fronteira seca Brasil-Argentina. Florianópolis: FundaçãoEditoraBoiteux, 2008.

SPIRO, P. J. Dual citizenship as Human Right.Int. J. Constitutional Law, v. 8, n. 1, p. 111-130, 2010.

SPIRO, P. J. Beyond citizenship: American identity after globalization. First Printing. Oxford: Oxford University Press, 2008.

STIGLITZ, J. E. Freefall: America, free markets, and the sinking of the world economy. New York: W. W. Norton \& Company, 2010.

STIGLITZ, J. E. Making globalization work. New York: W. W. Norton \& Company, 2007.

STIGLITZ, J. E. Globalization and Its discontents. New York: W. W. Norton \& Company, 2003.

TAFT, D. R.; DONALD, R.; ROBBINS, R. International migrations: the immigrant in the modern world / by Donald R. Taft, Richard Robbins. New York: The Ronald Press, 1955.

TAYLOR, A. L.; BETTCHER, D. W.; PECK, R. International Law and the International Legislative Process: a case study of the WHO Framework Convention on Tobacco Control. Global Public Goods and Health. Oxford: Oxford University Press, 2003.

THE LAW of Nationality.The American Journal of International Law, v. 23, n. 2, p. 1-129, 1929.

VALS, P. La nacionalidad. Revista de Derecho Puertorriqueño, Escuela de Derecho de la Pontificia Universidad Católica de Puerto Rico, v. 19, p. 135-240. 1981.

VAN CREVELD, M. Ascensão e declínio do Estado. São Paulo: Martins Fontes, 2004.

VITÓRIA, F. de. Os índios e o direito da guerra. Tradução de Ciro Mioranza. Ijuí: Unijuí, 2006. (Coleção Clássicos do Direito Internacional). Tradução de:De indis et de jure belli relectiones. 
WALZER, M. Spheres of Justice: a defense of pluralism and equality. New York: Basic Books, 1983.

WEIS, P. Nationality and statelessness in international law. Dordrecht, Netherlands: Kluwer Law International, 1979.

WENK, M. G. The refugee: a search for clarification. International Migration Review, v. 2, n. 3, p. 62-69, 1968.

WEISSBRODT, D. S.; DANIELSON, L. Immigration Law and Procedure in a Nutshell. 5th ed. New York: Thomson West, 2005.

WERBNER, P. The translocation of culture: migration, community, and the force of $\begin{array}{llll}\text { multiculturalism in history. SSRN } & \text { eLibrary. }\end{array}$ $<$ http://papers.ssrn.com/sol3/papers.cfm?abstract_id =739205> 